\title{
Informaatiolukutaito työpaikalla - ECIL 2017 konferenssin satoa
}

\author{
Marja Hjelt \\ Tampereen yliopisto \\ hjelt.marja.a@student.uta.fi
}

\section{Tuulikki Alamettälä}

Tampereen yliopisto

tuulikki.alamettala@uta.fi

\section{Jarmo Saarti}

Itä-Suomen yliopisto

jarmo.saarti@uef.fi

https://orcid.org/0000-0001-6565-0969

\begin{abstract}
The European Conference on Information Literacy (ECIL) was this year organised in France, Saint-Malo in September 2017. The main theme of the conference was workplace information literacy. In this report, the authors discuss in depth the main topic of the conference. There is also included a brief description of the current state and interest on the information literacy research based on the conference papers presented at the conference. The next ECIL will be in Oulu, Finland on September 24-27, 2018.
\end{abstract}

Asiasanat: informaatiolukutaito; työelämä; ECIL; konferenssit

Tämän vuoden European Conference on Information Literacy (ECIL) pääteemana oli informaatiolukutaito työtehtävien ratkaisemisessa teemalla "Workplace Information Literacy". Konferenssi pidettiin syyskuun puolivälissä, 18.-21.9. Ranskassa, Artikkeli on lisensoitu Creative Commons Nimeä-EiKaupallinen-JaaSamoin 4.o Kansainvälinen -lisenssillä 
Bretagnessa. Saint-Malon keskiaikainen kaupunki tarjosi viehättävät puitteet jo perinteeksi muodostuneelle konferenssille. Konferenssipaikkana oli alueen ainoa uudisrakennus, Le Grand Large - Palais des Congrès de Saint-Malo, jonka ikkunoista avautui silmiä hivelevä merimaisema.

Kutsutut esitelmöitsijät keskittyivät puheissaan tulevaisuuden työhön sekä siihen, kenen vastuulla työntekijän informaatiolukutaito on ja miten erityisesti työpaikan ja sen sisäisen kulttuurin merkitys näkyy tiedon evaluoinnissa. Esitykset olivatkin varsin inspiroivia ja avarsivat näkemystä informaatiolukutaidon merkityksestä työtehtävien ratkaisemisessa.

\section{Kuka välittää informaatiolukutaidosta työpaikalla?}

Bonnie Cheuk, ammatillisen tiedonhankinnan parissa pitkään työskennellyt, Euroclearin Digital Knowledge and collaboration -yksikön johtaja, haki keynote-esityksessään vastausta siihen, mikä merkitys informaatiolukutaidoilla on yritysmaailmassa. Oletetaanko, että kaikilla työntekijöillä on jo koulutuksen kautta riittävät taidot hakea, soveltaa ja tuottaa informaatiota? Odottavatko yritysjohtajat työntekijöitään informaatiolukutaidon ylläpitoa ja kehittämistä? Onko informaatiolukutaidolla merkitystä kirjastoalan ja informaatiotieteiden ulkopuolella?

Cheuk (2017) itse vastasi, että ilmaisulla "informaatiolukutaito" ei tarkoiteta mitään yritysmaailmassa, vaan informaatiolukutaito on naamioitu erilaisten leimojen alle, erilaisiin työprosesseihin. Tämän vuoksi itse informaatiolukutaitoon ei myöskään kiinnitetä huomiota työpaikoilla eikä sitä pidetä tärkeänä, tai kuten Cheuk korosti, että yritysmaailma ei osaa usein tunnistaa informaatiolukutaitojen tärkeyttä. Informaatiolukutaito voidaan kuitenkin huomioida paremmin, kun tunnetaan sen haasteet työpaikoilla ja aletaan puhua konkreettisista taidoista käsitteellisen puheen sijaan.

Yritysmaailmassa asiantuntijatyötä tekevät henkilöt toimivat tutkimus- ja kehittämistehtävissä, myynnissä ja markkinoinnissa, asiakaspalvelussa, ICT-tuessa, tuotehallinnassa ja liiketoiminta-analyysissä. Heidän työtehtävänsä perustuvat tiedon hankintaan ja tuottamiseen, mutta informaatiolukutaito on piilossa itse prosesseissa. Asiantuntijat kohtaavat erilaisia tiedontarpeita ja vaatimuksia eri aikoina - milloin tietoa tarvitaan toiminnan tehostamiseen tai kustannusten karsimiseen, milloin innovaatioiden kehittämiseen tai kriisin hallintaan - eri konteksteissa tiedon tarpeet määritellään ja tieto arvioidaan ja käsitellään eri tavoin. Ei siis ole olemassa yhtä oikeaa kaikkiin tilanteisiin sopivaa mallia työelämän informaatiolukutaidoista.

Yrittäjien ja johtajien sekä asiantuntijoiden näkemykset tiedontarpeesta ja tarvittavasta tiedosta ovat erilaiset. Cheuk totesi, että liikemiehet ovat kiinnostuneita 
informaatiosta, kun sitä pidetään strategian ja taktiikan kannalta tärkeänä esimerkiksi päätöksenteossa sekä tapaturmien ja kriisien välttämisessä. Hän kehottikin työpaikoilla näkemään suuremman kuvan, informaatiolukutaito on vain osa työntekijän työtä. Informaatiolukutaito on kontekstuaalista, erilaiset tilanteet ja olosuhteet edellyttävät erilaisia tietoja.

Cheuk näkee myös erilaiset yrityskulttuurit organisaatioissa informaatiolukutaidon haasteena. Yrityskulttuuri vaikuttaa voimakkaasti työpaikalla esiintyvän informaatiolukutaidon tasoon. Organisaatiot, joilla on avoin, verkottunut kulttuuri, arvostavat informaatiolukutaitoa, kun taas yrityksissä, joilla on hierarkkinen, komento- ja kontrollikulttuuri, sitä ei pidetä yhtä tärkeänä.

Informaatiolukutaidon merkitys työpaikalla kasvaa, kun informaatio nähdään strategisena mahdollisuutena ja erityisesti kun pystytään hahmottamaan sen taloudelliset vaikutukset. Informaatiolukutaidon merkitystä työpaikalla strategian suunnittelussa ja toiminnanohjauksessa voidaan kehittää kääntämällä huomio itse informaatiolukutaidosta kysymyksiin "mitä tietoa tarvitaan liiketoiminnan tulosten saavuttamiseksi" ja "millainen ympäristö voi mahdollistaa tehokkaan tiedonkulun". Cheuk näki työtehtävien ratkaisemisessa vaadittavan informaatiolukutaidon haasteina henkilökunnan, tieto-etiikan, organisaation arvot ja toimintakulttuurin sekä tietojärjestelmät. Haasteiden tunnistaminen ja ymmärtäminen muuttaa informaatiolukutaidon työpaikalla strategiseksi, tarkoitukselliseksi, käytännölliseksi, ketteräksi ja kontekstuaaliseksi.

Cheukin ehdotus naamioida informaatiolukutaidon käsite jonkun yritysmaailmaan paremmin uppoavan termin taakse ei saanut kuulijakunnan varauksetonta hyväksyntää. Jos informaatiolukutaidosta ei puhuta informaatiolukutaitona, koko käsitteen olemassaolo on vaarassa.

\section{Informaatiolukutaito ja tulevaisuuden työ}

InformAll:in johtajan, aiemmin informaatiolukutaidon kehittämishankkeiden parissa työskennelleen Stephane Goldsteinin kutsutun esityksen päämääränä oli tarjota näkökulmia sekä siihen, miten informaatiolukutaito on mukana yhteiskunnan kehityksessä ja tulevaisuuden skenaarioissa, että siihen, miten se myötävaikuttaa työntekijöiden kykyyn mukautua työssä tapahtuviin muutoksiin.

Aluksi Goldstein (2017) esitteli työssä tapahtuvia muutoksia. Hän näki organisaatiot verkostoina, joissa hierarkkiset rakenteet madaltuvat, ja jolloin myös urapolut muuttuvat enemmän horisontaalisiksi. Tämä lisää projektityötä ja tiimit ovat itsenäisempiä. Myös työn rutiininomaisuus vähenee automaation myötä.

Goldsteinin mukaan tulevaisuudessa työsuhteet tulevat olemaan yhä epävarmempia ja enemmän yrittäjälähtöisiä, työaika, -paikka ja -tehtävät muuttuvat epä- 
säännöllisiksi, ja työ tulee olemaan moni- ja sekamuotoista. Määräaikaisuus ja etätyö lisääntyvät. Myös työvoimassa tapahtuu muutoksia ja se on tulevaisuudessa "iätöntä" (pitkät työurat ja elinikäinen oppiminen), "tiedostavaa" (itsensä toteuttaminen ja hyvinvointi) ja "intuitiivista" (tunnustelee tunnelmia, halu ja tarve edistää vaistonvaraisuutta, vuorovaikutteiset työympäristöt).

Informaatiolukutaito vaikuttaa kaikkiin näihin tekijöihin, ja työntekijöiden tulee tehdä päätöksiä epävarmoissa ja heikosti ennustettavissa tilanteissa. Organisaatioiden muuttuessa demokraattisimmiksi tieto kulkee joka suuntaan, ei vain lineaarisesti. Yhteistyön lisääntyminen edellyttää joustavaa ja vuorovaikutteista työympäristöä ja työkulttuuria.

Esityksessään Goldstein nosti esiin myös sen, että ruusuiset näkemykset tulevaisuuden työpaikasta eivät kuitenkaan huomioi sitä, että on olemassa myös organisaatiolle marginaalisia työntekijöitä, joille työn muutokset aiheuttavat epävarmuutta. Hän kysyi, miten käy heikommin koulutetun työvoiman, kuten siivoojien, vartijoiden ja varastohenkilöstön? Ovatko he osallisia työpaikan informaatiokulttuurissa, mitkä ovat heidän tiedontarpeensa muuttuvassa työympäristössä? Onko heidän informaatiolukutaidon tasonsa riittävää selvitäkseen digitaalisessa maailmassa? Informaatiolukutaito onkin hyvin perustavaa laatua oleva yhteiskuntapoliittinen kysymys.

Työn joustavuus tuo Goldsteinin mukaan myös lisääntyviä mahdollisuuksia työn tarjontaan yli rajojen, keikkatyöhön ja yrittäjyyteen sekä työelämän sovittamiseen vapaa-aikaan. Mutta samalla se voi myös lisätä työntekijöiden paineita, heikentää etuja ja aiheuttaa syrjäytymistä. Uudet teknologiat antavat työnantajille mahdollisuuden kerätä tietoa työntekijöistään, mikä herättää huolta työntekijöiden valvonnasta, itsenäisyydestä ja tietosuojasta. Goldsteinin mukaan informaatiolukutaitoa voitaisiinkin soveltaa myös työntekijöiden oikeuksien puolustamiseen.

Informaatiolukutaidolla on paikkansa myös työvoiman uudelleenkoulutuksessa, sillä se liittyy elinikäiseen oppimiseen ja auttaa yksilöitä navigoimaan yhä monimutkaisemmilla urapoluilla. Informaatiolukutaito voi auttaa ihmisiä myös sopeutumaan työn muutokseen. Esimerkiksi automaation kehitys ja digitalisaatio koskettaa lähes kaikkia ja herättää kysymyksen, mitä työtehtäviä jää enää ihmisille suoritettaviksi. Goldsteinin mukaan tulevaisuuden työn näkymässä ihmiselle jää luova työ, joka vaatii henkilökohtaista vuorovaikutusta ja verkottumista. Goldstein päätti esityksenä kysymykseen, kuinka informaatiolukutaito voisi vastata sekä tulevaisuuden uhkakuviin, että mahdollisuuksiin. Hän korosti, että on tärkeää tarkastella molempia. 


\section{Informaatiolukutaito ja akateeminen toimintaympäristö - työelämätaitojen ja opiskelutaitojen välinen kuilu}

Ecole hôtelière de Lausannen kirjaston- ja arkistonjohtaja, opettaja, luennoitsija ja kirjailija Jean-Philippe Accart (2017) pohdiskeli kutsutussa esityksessään yliopistoopiskelijoiden informaatiolukutaitojen ja työllistymisen yhteyttä. Hän käytti esimerkkinä Sveitsiä, jossa vuonna 2011 määriteltiin ja otettiin käyttöön informaatiolukutaidon standardit yliopistotasolla. Accart esitteli kaksi eri oppilaitosta, joissa informaatiolukutaidon opetus on voimassa olevista standardeista huolimatta kovin eri tasolla.

Geneven yliopiston matemaattis-luonnontieteellinen tiedekunta tarjoaa monipuolista informaatiolukutaidon opetusta kautta opintojen ja opiskelijat valmistuvat sieltä hyvin informaatiolukutaidoin varustettuina. Sen sijaan yksityisessä hotellikoulussa Ecole hôtelière de Lausannessa, jossa Accart itse työskentelee, informaatiolukutaidon opetus on huomattavasti vähäisempää, vaikka sieltä valmistuneiden työtehtävien perusteella informaatiolukutaidoille olisi tarvetta. Tämä ei silti tunnu olevan este työllistymiselle, sillä sieltä valmistuneilla on erinomaiset työllistymismahdollisuudet. Cheukin tavoin Accart kysyi, onko informaatiolukutaito minkäänlainen edellytys menestykselle työelämässä ja onko sillä mitään arvoa työnantajien silmissä?

Accart totesi, että informaatiolukutaitoja ei kuuluteta työpaikkailmoituksissa eikä niitä kirjata työsopimuksiin. Ja se, ettei taitoja vaadita ja jos niitä varsinkaan ei ole, johtaa Accartin mukaan ajan ja energian hukkaan ja tehottomuuteen informaation hallintaa vaativissa työtehtävissä. Accart totesi, että kaikkien tulisi osata etsiä ja arvioida kaiken tyyppistä tietoa kriittisesti, ja siksi opiskelijoiden informaatio- ja digitaalisia lukutaitoja pitäisi kehittää edelleen, aloittamalla niiden opetus varhain ja mittaamalla niiden edistymistä eri vaiheissa opintoja

\section{Informaatiolukutaidon keskeiset tutkimuskohteet}

Konferenssissa esiteltiin 253 erityyppistä esitystä aina tutkimusartikkeleista postereihin ja lyhyempiin suullisiin esityksiin. Esiintyjät olivat 57 eri maasta, joten voi väittää, että niiden kautta saa hyvän kuvan informaatiolukutaitoon liittyvästä tutkimuksesta ja käytänteiden kehittämisestä työstä ympäri maailmaa. Työelämään ja opiskelijoiden informaatiolukutaitoon liittyvät tematiikat olivat keskeisiä konferenssissa.

Akateemisessa ympäristössä uutena kehittämisen kohteena on avoimen tieteen nopea kehitys ja siihen liittyvät erityistaidot. Tähän liittyi useita hankkeita, joissa selvitettiin tutkijoiden ja opiskelijoiden osaamista tekijänoikeuksiin liittyen ja 
erityisesti datan avaamisessa, joka on erityinen informaatioympäristö ja selkeästi nousemassa kirjastojen toimintakenttään keskeiseksi tehtäväksi.

Viimeaikainen keskustelu internetin valeuutisista ja kansalaisten informaatioympäristön politisoitumisesta nousi myös esille. Näyttää siltä, että kansalaiskasvatus ja informaation arviointiin liittyvien kykyjen kehittäminen on tulossa entistä tärkeämmäksi osaksi kansalaisinformaatiolukutaitoja. Opiskelun ja työelämän lisäksi siis kolmannen sektorin, vapaa-ajan ja kansalaisyhteiskunnan vaatimat taidot kriittiseen informaation hyödyntämiseen alkavat nousta esille sekä tutkimuksessa että taitojen ja niiden opettamisen kehittämissä.

Lisäksi konferenssissa huomasi sekä esitelmissä että keskusteluissa, että käsitekriittinen keskustelu informaatiolukutaidosta ja sen alasta on myös hyvässä vauhdissa. Välillä alkoi esitelmiä kuunnellessa tuntua siltä, että informaatiolukutaito on kärsinyt inflaation, kun sitä on alettu osin kritiikittömästi hyödyntää kaikille elämänalueille ja kaikkeen alamme tutkimukseen. Aihealueella onkin selkeä tarve kriittiseen käsiteanalyysiin ja sen pohdintaan, mihin kaikkeen informaatiolukutaito käsitteenä ja ilmiönä on sovellettavissa. Ja erityisesti siihen, kannattaako informaatiolukutaidolla aina myydä perinteisiä tiedon käyttämisen, luomisen ja soveltamisen taitoja.

\section{Suomalainen informaatiolukutaitotutkimus esiintyi vahvana}

Suomi oli jälleen kerran erinomaisen hyvin edustettuna konferenssissa. Paikalle oli tullut sekä tutkijoita että kirjastoalan ammattilaisia ympäri Suomea. Esitelmiä oli muun muassa seuraavista aiheista: informaatiolukutaidon opetus (Alamettälä \& Sormunen), nettitiedonhakutaitojen testaaminen (Sormunen \& al), tieteentekijöiden käsitykset tutkimusdatan hallinnasta ja jakamisesta (Enwald, Kortelainen \& Huotari), tiedon jakaminen (Heinström \& Ahmad), kirjastostrategiat (Hjelt \& Saarti) sekä opettajien ja koulukirjastonhoitajien yhteistyö (Ojaranta). Näkyvimmin esillä oli kuitenkin Oulun yliopiston informaatiotutkimuksen oppiaineessa tutkimuskohteena oleva terveystiedon lukutaito, jolla oli oma sessionsa konferenssissa. Tämä olikin hyvää harjoitusta Oulun yliopiston edustajille, sillä vuoden 2018 ECILkonferenssi järjestetään Oulussa 24.-17. syyskuuta. Konferenssin teemana on Information Literacy in Everyday Life ja sen esitelmäkutsu on avattu.

Suomessa alkaa muodostua alan tutkimuksessa jo omia koulukuntia ja selkeitä kiinnostuksen kohteita. Lisäksi aiheeseen liittyviä kehittämishankkeita ja kokeiluja on käynnissä eri organisaatioissa. Aktiivisimpina toimijoina tuntuvat olevan edelleen korkeakoulut, mutta on ilahduttavaa, että peruskoulutuksessa alkaa myös näkyä aktiivinen informaatiolukutaitotyö. 
Selkein - ainakin konferenssin perusteella - kehittämiskohde Suomessakin on informaatiolukutaitojen ja niiden oppimisen tukeminen ja niihin liittyvien käytänteiden tukeminen kouluympäristön ulkopuolella. Viime aikojen suomalainen tietoyhteiskuntakehitys ja digitaalisuuspuhe tuntuvat edelleen keskittyneen palveluiden ja infrastruktuurin kehittämiseen. Tämä julkinen keskustelu ei tunnu aina muistavan suurta tarvetta kansalaistaitojen ja työelämätaitojen kehittämiseen informaation käytön mahdollistajana kaikissa ikäluokissa ja toimintaympäristöissä. Tässä olisi meidän alallemme paljon tehtävää sekä tutkimuksellisesti että käytänteiden luomisessa.

\section{Informaatioähkyä ja kohti ECIL 2018 Oulua}

Vuonna 2013, ensimmäisen ECIL-konferenssin jälkeen, konferenssiraportissa todettiin: "Kun ohjelma alkaa 8:30, ei mieli pysy enää virkeänä klo 18 jälkeisissä istunnoissa. Monta kiinnostavaa esitystä jäi myös kuulematta rinnakkaisissa sessioissa." (Saarti, Kämäräinen, \& Sormunen, 2013). Samat sanat voi todeta tänäkin vuonna, konferenssin täyttäessä viisi vuotta. Konferenssipäivät olivat pitkiä ja neljä rinnakkaissessiota takasi sen, että välillä oli pakko tehdä vaikeita valintoja. Informaatioähky valtasi helposti ja osallistujien omat informaatiolukutaidot olivat koetuksella.

Neljä vuotta sitten kirjoittajat myös toivoivat, että päätös konferenssin järjestämisestä vuosittain ei hyydyttäisi hyvää ideaa alkuhuuman haihduttua (Saarti ym., 2013). Toive on toteutunut, sillä ECIL on edelleen hyvissä voimissa ja kerää joka vuosi yhteen satoja tutkijoita ja kirjastoalan ammattilaisia ympäri maailmaa, seuraavan kerran siis Suomessa. Meillä on nyt tuhannen taalan paikka näyttää osaamistamme ja tutkimustamme kollegoillemme. Siispä tapaamisiin Oulussa syksyllä 2018 !

Tämänvuotisen konferenssin abstraktijulkaisu löytyy internetistä (ECIL, 2017) ja siihen kannattaa tutustua jo senkin vuoksi, että se antaa hyvän kokonaiskäsityksen aiheen kehittämis- ja tutkimustyöstä koko maailmassa. Konferenssijulkaisut ilmestyvät vuoden 2018 alkupuolella samassa Springerin kustantamassa sarjassa kuin aikaisemmatkin: Communications in Computer and Information Science.

\section{Lähteet}

Accart, J.-P. (2017). Information Literacy (IL) in the academic context: is there a gap between employability competencies and student information literacy skills? Presentation at European Conference on Information Literacy (ECIL) 21.9.2017. Saint-Malo, France. https://www.slideshare. net/jpa245/students-information-literacy-skills-and-employability (luettu 31.12.2017) 
Cheuk, B. (2017). Who cares about information literacy in the workplace? Presentation at European Conference on Information Literacy (ECIL) 18.9.2017. Saint-Malo, France. https://www. slideshare.net/secret/vF3tdBP81DaZhl (luettu 31.12.2017)

ECIL. (2017). Fifth European Conference on Information Literacy (ECIL) - Abstracts. (S. Špiranec, S. Kurbanoğlu, J. Boustany, E. Grassian, D. Mizrachi, L. Roy, \& D. Ko, Toim.). Saint-Malo, France. http://bit.ly/ecil-2017-abstracts (luettu 31.12.2017)

Goldstein, S. (2017). Information Literacy and the Future of Work. Presentation at European Conference on Information Literacy (ECIL) 19.9.2017. Saint-Malo, France. https://www. slideshare. net/rincic2014/presentation-to-ecil-2017-il-and-the-future- of-work (luettu 31.12.2017)

Saarti, J., Kämäräinen, J., \& Sormunen, E. (2013). Informaatiolukutaitoa määrittelemässä - ECIL 2013 konferenssi Istanbulissa. Informaatiotutkimus, 32(3-4). https://journal.fi/inf/article/view/ 9443 (luettu 31.12.2017) 